\title{
URGENSI DAN KONSEKUENSI TERHADAP PENGADILAN HAM REGIONAL ASEAN DI BAWAH AICHR
}

\author{
Dewa Gede Sudika Mangku \\ Fakultas Hukum dan Ilmu Sosial, Universitas Pendidikan Ganesha \\ Bali, Indonesia \\ Email: dewamangku.undiksha@gmail.com
}

\begin{abstract}
ABSTRAK
Pada 2009, ASEAN berhasil membentuk Badan Hak Asasi Manusia mereka sendiri bernama AICHR. Fungsi, tugas dan wewenang sebagaimana diatur dalam TOR AICHR adalah untuk mempromosikan dan melindungi hak asasi manusia di wilayahnya. Namun, fungsi perlindungan yang diamanatkan untuk AICHR masih belum dapat dicapai. Buktinya, banyak kasus pelanggaran HAM yang terjadi di kawasan Asia Tenggara tidak bisa diselesaikan di tingkat nasional. Semua alasan di atas terbukti bahwa ASEAN membutuhkan Pengadilan Hak Asasi Manusia yang bertujuan untuk mendapat keadilan. Hasil dari penelitian ini ialah terdapat beberapa faktor penghambat AICHR dalam penegakan HAM di Asia Tenggara, diantaranya prinsip ASEAN Way dimana penggunaan prinsip non intervensi dan kedaulatan negara ASEAN untuk hak asasi manusia yang masih belum fleksibel; pengambilan keputusan berdasarkan konsensus yang membuat kinerja AICHR menjadi terhambat karena harus mendapat suara bulat dari seluruh negara anggota ASEAN; lemahnya mandat fungsi proteksi dalam ToR AICHR karena tidak tercapainya konsensus. Metode penelitian yang digunakan dalam peneitian ini dilakukan dengan menggunakan metode penelitian normatif dengan mengumpulkan data sekunder studi perpustakaan yang studi ini berasal dari data sekunder.
\end{abstract}

\section{Kata Kunci: Pengadilan HAM ASEAN; Urgensi; Konsekuensi.}

\begin{abstract}
In 2009, ASEAN succeeded in establishing their own Human Rights Body called AICHR. The functions, duties and powers as stipulated in the AICHR's TOR are to promote and protect human rights in their territories. However, the protection functions mandated for AICHR have not yet been achieved. The proof is that many cases of human rights violations that have occurred in Southeast Asia cannot be resolved at the national level. All the reasons above are proven that ASEAN needs a Human Rights Court which aims to get justice. The results of this study are that there are several factors inhibiting AICHR in upholding human rights in Southeast Asia, including the ASEAN Way principle where the use of non-intervention principles and ASEAN state sovereignty for human rights is still not flexible; consensus-based decision making which hampered AICHR's performance because it had to get unanimous votes from all ASEAN member countries; the weak mandate of the protection function in the AICHR ToR because consensus was not reached. The research method used in this research is carried out using normative research methods by collecting secondary data from library studies which this study comes from secondary data.
\end{abstract}

Keywords: ASEAN Human Rights Court; Urgency; Consequences. 


\section{A. PENDAHULUAN}

Dari berbagai pelanggaran HAMyang terjadi, maka upaya represifyang seharusnya dilakukan oleh negara-negara ASEAN adalah dengan membentuk sebuah pengadilan HAM yang dapat beroperasi dalam wilayah ASEAN, dimana nantinya pengadilan HAM tersebut menjadi wadah untuk menyelesaikan masalah-masalah internal ASEAN. Mengingat prinsip non-interference yang dimiliki ASEAN menjadikan anggota-anggotanya tidak mampu mencampuri urusan negara anggota lainnya. Fakta empirisnya, pelaksanaan prinsip non-intervensi saat ini justru menyebabkan krisis kemanusiaan baik secara internal dalam suatu negara yang berkonflik maupun eksternal yang merambah ke negara lain khususnya di wilayah ASEAN. Sehingga individu maupun kelompok yang mengalami tekanan dari adanya ketidakstabilan di wilayah pemerintahan suatu negara tidak dapat mengakses aspek-aspek utama dari human security yang dicanangkan oleh $\mathrm{PBB}$, khususnya keamanan bagi diri sendiri (personal security). Hal tersebutlah yang menjadi penghambat pemajuan dan perlindungan HAM di ASEAN karena negara-negara ASEAN masih cenderung membentengi diri di balik prinsip non-intervensi.

Kasus rohingya yang menjadi kasus pelanggaran HAM yang sudah terjadi sejak sekitar tahun 1960. Kasus pelanggaran HAM ini terjadi berlarut-larut tanpa ada penyelesaian yang pasti. Pelanggaran HAM yang terjadi pada penduduk Rohingya terjadi karena isu etnis, penduduk Burma yang merupakan mayoritas di Myanmar menganggap penduduk Rohingya bukan merupakan bagian dari Negara Myanmar karena secara fisik dianggap berbeda oleh penduduk Burma. Penduduk Rohingya dianggap imigran asal Bangladesh yang masuk ke Myanmar. Isu agama pun menjadi persoalan dalam kasus pelanggaran HAM yang terjadi pada penduduk Rohingya yang beragama Islam. Mirisnya, pelaku dari kasus pelanggaran HAM ini bukan individual melainkan Negara, militer dan pemerintahnya. Salah satu fakta empirisnya, adanya usaha kudeta oleh pihak militer untuk mengambil pemerintahan yang membuat penduduk Rohingya tidak diperkenankan untuk ikut berpartisipasi dalam pemerintahan. Pada tahun 1978 pemerintah juga jelas telah melakukan "Operasi Raja Naga” di wilayah Rakhine dengan target penduduk Rohingya.

ASEAN sendiri sebenarnya telah memiliki Komisi HAM antar negara ASEAN atau The ASEAN Intergovernmental Commission on Human Right (AICHR) yang telah dibentuk pada tahun 2009 dan dapat dimanfaatkan sebagai instrumen penegakan HAM di kawasan. Akan tetapi AICHR tidak akan bisa berbuat banyak dalam pengentasan masalah Rohingya. Komisi ini diperkirakan hanya bisa mendorong setiap negara anggota untuk menjunjung dan melindungi nilai-nilai HAM. Prinsip non-intervensi yang mempengaruhi perumusan mandat ASEAN InterGovernmental Comission on Human Rights (AICHR) yang terkesan tidak seimbang antara fungsi promosi dan fungsi proteksi. Berbagai kepentingan politik yang sangat beragam menjadikan standar hukum nasional masing-masing negara ASEAN superior dibandingkan mandat AICHR. Tingginya pelanggaran HAM di negara-negara anggota ASEAN yang tidak diimbangi dengan upaya perlindungan secara komprehensif di kawasan tersebut. Dilema nonintervensi dengan inisiasi pembentukan pengadilan HAM ASEAN dalam konflik kedaulatan negara-negara Asia Tenggara. Mengingat wilayah Asia Tenggara yang berpenduduk heterogen, sehingga munculnya konflik horizontal dan vertikal sangat rentan terjadi. Sehingga urgensi dan konsekuensi dari dibentuknya pengadilan HAM menjadi suatu bahan tersendiri yang patut dikritisi.

\section{B. METODE PENELITIAN}

Penelitian ini menggunakan penelitian hukum normatif yang metodenya berdasarkan pada kajian aplikasi dan relevansi dari teori-teori dalam studi Hukum HakAsasi Manusia Internasional. 
Pengumpulan data dilakukan dengan metode studi kepustakaan dengan mengumpulkan bahan hukum dan informasi. Penelitian ini menggunakan data sekunder dengan bahan hukum dalam penelitian yang di ambil dari studi kepustakaan yang terdiri dari bahan hukum primer, bahan hukum sekunder dan bahan non hukum. Bahan hukum primer dan sekunder yang dikumpulkan kemudian dilakukan evaluasi, interpretasi, dan argumentasi dengan menggunakan metode preskriptif. Penelitian hukum normatif atau kepustakaan tersebut mencakup penelitian terhadap asas-asas hukum, penelitian terhadap sistematik hukum, penelitiann terhadap taraf sinkronisasi vertikal dan horizontal, perbandingan hukum, sejarah hukum ${ }^{1}$. Berdasarkan pada perumusan masalah dan tujuan dari penelitian yang merupakan penelitian yuridis normatif, maka pendekatan yang digunakan dalam penelitian ini adalah pendekatan undang-undang (statute approach), pendekatan kasus (case approach) serta pendekatan analasis (analytical approach). Berdasarkan Statuta Approach penulis akan menganalisa dan mengkritisi TOR AICHR, ASEAN Charter, dan beberapa instrument HAM lainnya baik ditingkat ASEAN maupun internasional. Case approach digunakan untuk menganalisis contoh kasus yang terjadi di ASEAN terkait penegakan HAM dan alasan mengapa pengadilan HAM memang ada urgensi untuk dibentuk.

\section{PEMBAHASAN}

\section{Efektivitas Kontribusi AICHR Dalam Penegakan HAM}

Kontribusi AICHR sendiri tengah menjadi sorotan dan mendapatkan kritikan yang cukup tajam dari kalangan kelompok masyarakat sipil. Diantara ke kendala dan kelemahan-kelemahan tersebut, antara lain:

1. Terdapat Kepentingan Politik dari Masing-masing Negara ASEANyang didalamnya mencakup perbedaan perkembangan demokrasi dan HAM yang tajam diantara negara anggota ASEAN. Political diversity di dalam ASEAN sendiri tetap menjadi persoalan ketika hendak mencapai kesepakatan dalam persoalan HAM;

2. AICHR sebagai lembaga antar pemerintah, dalam bekerjanya lebih sebagai lembaga negosiasi politik ketimbang Lembaga HAM;

3. Penerapan prinsip non-intervensi yang relatif masih kaku dan konservatif

4. Independensi yang lemah: dari segi keanggotaan, tanggung jawab/akuntabilitas anggota pada pemerintah yang menunjuk, dari segi pendanaan.

5. Lemahnya Mandat Fungsi Proteksi Dalam ToR AICHR (mekanisme proteksi yang lemah): tidak ada wewenang menerima pengaduan individual, wewenang untuk investigasi, wewenang untuk country visit, dan tidak ada pembahasan country situation. Komisi, juga tidak dapat menjatuhkan sanksi atas pelanggaran HAM yang terjadi di suatu negara dan pembahasan masalah HAM hanya dapat dilakukan dalam tingkat dialog.

6. TidakmemilikimandatinvestigatifdankoersifyangmembuatPelanggaranHAMdkawasan Asean tidak dapat dimasuki AICHR. AICHR terikat dengan norma dan standar organisasi tradisional Asean yang lebih menekankan Asean Way, yakni konsensus, kedaulatan negara dan non intervensi ${ }^{2}$

Di mana beberapa faktor tersebut akan diulas lebih dalam di beberapa penjelasan berikut ini:

1 Soekanto, S., \& Mamudji, S. (2011). Penelitian Hukum Normatif Suatu Tinjauan Singkat, Jakarta: PT Raja Grafindo Persada, hlm. 51.

2 AICHR. 2019. Prospek Mekanisme HAM ASEAN. Diakses dari https://aichr. or.id/index.php/id/aichrindonesia/akuntabilitas-publik/rilis/23-prospek-mekanisme-hamasean? showall=\&start $=4$, pada tanggal 15 Juni 2020, pukul 17.56 WIB. 


\section{a. ASEAN Way}

ASEAN Way dikenal sebagai suatu pendekatan negara-negara di Asia Tenggara terhadap kerjasama politik dan keamanan yang condong mengacu pada cara pengambilan keputusan, namun beberapa ahli mendefinisikannya lebih sebagai sebuah norma dan gaya hidup negaranegara ASEAN. Dikatakan sebagai penghambat karena berkaitan dengan ketidakmampuan AICHR untuk melakukan fungsi proteksi secara langsung pada segala permasalahan HAM yang berimplikasi regional yang membuat eksistensi dan independensi AICHR menjadi sangat dipertanyakan. Hal ini dikarenakan adanya prinsip non intervensi dan kedaulatan dari sebuah negara yang membatasi kinerja AICHR sebagai sebuah komisi HAM regional. ${ }^{3}$ Prinsip non-intervensi dan kedaulatan yang terdapat dalam ASEAN Way juga dikatakan menjadi penghambat penegakan HAM karena tidak sejalan dengan prinsip/norma R2P (Responsibility to Protect) yang menyatakan bahwa kedaulatan sebuah negara bukanlah hak mutlak dan negara kehilangan sebagian kedaulatannya apabila negara gagal melindungi penduduknya dari kejahatan dan pelanggaran HAM berat. $^{4}$

\section{b. Pengambilan Keputusan Berdasarkan Konsensus}

Salah satu kendala utama dalam pergerakan yang signifikan ialah sistem konsensus dimana AICHR, dan seluruh negara anggota ASEAN menjalankan. Model pengambilan keputusan dibuat awalnya dimaksudkan untuk memastikan bahwa semua negara sama, sejalan dengan kebijakankebijakan yang tanpa campur tangan dan penghormatan terhadap kedaulatan nasional. Bahkan jika salah satu dari negara anggota ada yang tidak setuju dengan agenda, konsensus tidak bisa dikatakan telah tercapai. Akan tetapi cara seperti itu sekarang menjadi penghambat utama bagi AICHR, khususnya sejak para perwakilan ditunjuk oleh pemerintah, dengan berbagai tingkat independensinya. Ketika beberapa diplomat atau pejabat yang diangkat oleh negara menunjukkan diri mereka cukup berpikiran independen, yang lainnya bisa berakhir dengan lebih fokus untuk membela pemerintahan mereka ketimbang terlibat secara sungguh-sungguh dalam pembahasan yang sulit. Dalam konteks dimana pemerintahan ASEAN sendiri adalah melakukan atau terlibat dalam pelanggaran terhadap hak asasi manusia, model konsensus dengan cepat bisa menjadi penghalang dan bukannya kekuatan. Alih-alih mendapatkan cara terbaru untuk menghasilkan keputusan yang bermanfaat, AICHR memilih angka pembagi umum yang terendah, topik yang paling tidak kontroversial untuk dipelajari ataupun kegiatan lain, dan bersikap diam dalam menanggapi bahkan pelanggaran hak asasi manusia paling serius di kawasan tersebut. ${ }^{5}$

3 Fiari Larasati Putri Irawan, Agus Subagyo, Jusmalia Oktaviani. Faktor-Faktor Penghambat Asean Intergovernmental Commission on Human Rights (Aichr) Dalam Penegakan Hak Asasi Manusia di Asia Tenggara. Dinamika Global, Volume 02, No.01, Juni 2017.

4 Heribertus Jaka Triyana. Tinjauan Yuridis Tentang Badan HAM ASEAN Dalam Sistem Hujum Nasional di Indonesia. Diakses darihttp://download.portalgaruda. org/article.php? article $=281587 \& v a l=7175 \&$ title $=$ tinjauan $\% 20 \mathrm{y}$ uridis $\% 20 \operatorname{tentan} \% 20 \mathrm{~g} \% 20$ badan\%20ham\%20asean\%20dalam\%20sistem\%20hukum\%20nasional\%20indonesia, pada tanggal 16 Juni 2020, pukul 14.31 WIB.

5 Kirsten Han, Teguh ahap. 2018. Menimbang efisiensi AICHR untuk perjuangan HAM di ASEAN. Diakses dari

https://newnaratif.com/journalism/menimbang-efisiensi-aichr-untuk-perjuangan-ham-di asean/share/xuna/acfe22eeddf82266e32f8f17912d59fe, pada tanggal 03 Juni 2020, pukul 16.37 WIB. 
Sehingga ketimpangan antara fungsi pemajuan dan perlindungan yang dimiliki oleh AICHR terlehat elas dari adanya 14 mandat AICHR yang diatur dalam TOR, mengingat hanya dua mandat yang spesifik menunjukkan implementasi dari fungsi perlindungan yakni mandat pengumpulan informasi terkait perkembangan implementasi promosi dan perlindungan HAM di masing-masing negara anggota dan mandat untuk melakukan kajian studi tematik terkait HAM di ASEAN. Kedua mandat tersebut pun dirasa masih kurang dalam upaya penanganan terhadap praktek pelanggaran HAM di ASEAN. Selain itu, kurangnya independensi dalam mekanisme pengambilan keputusan AICHR juga menjadi salah satu faktor penghambat AICHR. Dalam pengambilan keputusan, AICHR menggunakan prinsip konsensus yang merupakan dasar pencapaian keputusan regional AICHR. Dengan kata lain, AICHR baru dapat mengambil keputusan terhadap suatu kasus apabila sudah ditetapkan secara bulat oleh para komisioner AICHR dan juga Menteri Luar Negeri negara-negara anggota ASEAN. Keterlibatan Menteri Luar Negeri negara-negara anggota ASEAN dalam pengambilan keputusan menggambarkan bahwa AICHR sebagai perpanjangan tangan dari negara-negara anggota ASEAN. AICHR juga terkesan tidak independen dan netral karena keputusan yang diambil harus secara bulat. Sebagai contoh ketika Indonesia sudah pernah menawarkan agar AICHR mempunyai 3 mandat untuk melakukan fungsi proteksi yang diantaranya: wewenang menerima individual complaint, wew enang untuk investigasi, dan wewenang untuk country visit, tetapi di tolak dan tidak mencapai konsensus pada Rapat Menteri Luar Negeri ASEAN ke-43 Menteri (AMM) pada bulan Juli 2010 .

\section{c. Perbedaan Pandangan Masing-Masing Negara ASEAN terhadap HAM}

Cara pandang negara-negara ASEAN terhadap HAM masih sangat beragam. Hal ini tidak terlepas dari beragamnya kondisi social politik masing-masing negara anggota. Selain itu, di antara negara-negara ASEAN juga terdapat perbedaan interpretasi HAM antara universalis vs. partikularis ${ }^{6}$ Sementara itu, Bauer (1995) mengatakan, adanya perbedaan pandangan dari masingmasing negara anggota ASEAN terhadap hak asasi manusia ini dipengaruhi oleh beberapa hal:

1. Keragaman yang begitu kental di kawasan tersebut sehingga sulit untuk menetapkan standar umum mengenai hak asasi manusia;

2. Prioritas negara-negara dalam membangun bangsanya masingmasing serta memberantas kemiskinan;

3. Masih adanya pemerintahan otoriter pada beberapa negara di Asia Tenggara

Contoh paling buruk yang terjadi di kawasan ASEAN adalah tidak ada satupun negara dari Perhimpunan Bangsa-Bangsa Asia Tenggara (ASEAN) yang memiliki catatan hak asasi manusia yang cukup memuaskan. Komisi HAM Antar-Pemerintah untuk Hak Asasi Manusia yang terdiri atas perwakilan dari 10 negara anggota, sebenarnya memiliki mandat "mengembangkan strategi untuk dukungan dan perlindungan hak asasi manusia serta kebebasan yang fundamental" di dalam ASEAN. Namun AICHR telah mendapat kecaman sepanjang keberadaannya karena dianggap tidak efektif. Bahkan menurut pendapat Emerlynne Gil, penasehat senior hukum internasional di Komisi Internasional Ahli Hukum untuk Asia Tenggara, AICHR sekarang bukanlah sebuah lembaga perlindungan terhadap hak asasi manusia. Malahan sebaliknya, AICHR dipandang sebagai sebuah lembaga yang harus dibina lebih lanjut agar efektif dalam menangani masalah hak asasi manusia di kawasan ASEAN. Ketika komisi tersebut mendekati

6 Lidya Christin Sinaga. (2016). Mengurai Peran Indonesia Dalam Penguatan AICHR". LembagaIlmuPengetahuanIndonesia. Diakses dari http://www.politik.lipi.go.id/ kolom/kolom1/politikinternasional/1000-mengurai-peran-indonesiadalam-penguatanaichr, tanggal 05 Juni 2020. 
tahun ke-10 mereka, perwakilan untuk AICHR menjelaskan tentang tantangan struktural termasuk pembatasan pendanaan dari Mitra Dialog Eksternal ASEAN yang membuat mereka tertinggal dalam hal perlindungan hak asasi manusia di kawasan tersebut.

\section{d. Kurangnya Komitmen dari Masing-masing Negara ASEAN Karena Prinsip Non-Inter- vensi yang Mendominasi}

AICHR sebenarnya dapat dimanfaatkan sebagai instrumen penegakan HAM di kawasan. Akan tetapi, AICHR tidak bisa berbuat banyak dalam pengentasan masalah Rohingya. Komisi ini cenderung hanya bisa mendorong setiap negara anggota untuk menjunjung dan melindungi nilainilai HAM. Sesungguhnya, prinsip non-interfensi dapat menjadi benteng dalam dari konflik militer antar negara ASEAN. Namun jika dilihat dari sudut pandang HAM, prinsip ini disinyalir justru menjadi tameng untuk bertidak apatis terhadap adanya pelanggaran HAM dan tentunya sudah tidak relevan lagi dengan perkembangan HAM yang lebih mengedepankan prinsip kesetaraan dan anti penindasan serta prinsip tanggung jawab negara dan penegakan hukum. Tanggung jawab untuk melindungi atau Responsibility to Protect (R2P) merupakan salah satu prinsip internasional yang diusung oleh PBB, bahkan memungkinkan adanya intervensi langsung dari suatu negara jika ada negara lain dianggap telah gagal dan lalai melindungi warganya sendiri dari kekerasan dan kejahatan perang. R2P merupakan sebuah prinsip internasional yang digagas guna mencegah kejahatan kemanusiaan seperti pemusnahan massal, kejahatan perang, pembersihan etnis dan kejahatan kemanusiaan lainnya terjadi di suatu negara. Jika dengan berbagai sebab, suatu negara tidak mampu atau tidak memiliki kemauan untuk melindungi rakyatnya, maka menjadi tanggung jawab komunitas internasional untuk melakukan intervensi mencegah kejahatan kemanusiaan. Negara-Negara yang tergabung dalam ASEAN seyogyanya tidak dapat melakukan tindakan untuk menyelesaikan permasalahan karena prinsip non-intervensi yang telah menjadi prinsip dasar atau"golden rule" dalam keanggotaan ASEAN.

Prinsip non-intervensi yang terdapat dalam Piagam ASEAN selama ini dipegang teguh oleh para anggota ASEAN dalam kebijakan regionalnya menyebabkan negara-negara anggota tidak memiliki legitimasi dan otoritas yang cukup untuk mengintervensi masalah konflik dan pelanggaran HAM internal negara-negara anggotanya. Pasal 2 Piagam ASEAN menyatakan bahwa "(e) non-interference in the internal affairs of ASEAN member states, (f) respect the right of every member state to leads its national existence free from external interfence, subversion and coercion" menjadi dasar fundamental bagi hubungan antar anggota ASEAN. Memang nilai positif dari adanya prinsip ini yaitu mencegah dan meminimalisasi terjadinya konflik antar negara anggota ASEAN. Namun intervensi kemanusiaan sebenarnya dapat dikatakan sah apabila tidak melanggar batasan yang ditentukan oleh ketentuan Pasal 2 Ayat (4). Legalitas intervensi kemanusiaan kemudian juga dihubungkan dengan tujuan PBB untuk menghormati hak asasi manusia (Pasal 1 Ayat (3) Piagam PBB). Mengingat tujuan adanya Hukum Internasional adalah untuk membatasi kedaulatan negara itu sendiri. Sejak individu menjadi subyek Hukum Internasional, maka sebenarnya kedaulatan negara itu diperoleh dari individu yang mendelegasikan kewenangannya kepada negara. Jadi, ketika negara telah melanggar hak-hak individu, maka para individu tersebut dapat meminta bantuan kepada pihak lain (negara) untuk memulihkan hak-hak mereka. Pada saat itulah intervensi kemanusiaan menjadi eksis dan timbul kewajiban negara untuk melakukan kerjasama (bantuan) antara mereka untuk melindungi dan mempromosikan hak asasi manusia. Namun sayangnya komitemen dari masing-masing negara ASEAN sangat kurang karena banyaknya sikap pengutamaan kepentingan politik sehingga lupa untuk menghormati hak individu. 


\section{e. Lemahnya Mandat Fungsi Proteksi Dalam Term of Reference (ToR) AICHR}

Terkait dengan lemahnya mandat fungsi proteksi dalam ToR AICHR sangat berkaitan erat dengan adanya pengambilan keputusan yang harus berdasarkan konsensus sehingga salah satu pihak yang tidak menyetujui terhadap rencana kebijakan maka tidak akan pernah mencapai konsensus. Sehingga lemahnya mandat fungsi proteksi dari ToR AICHR dikarenakan tidak tercapainya suatu konsensus dari rencana kebijakan untuk menerima wewenang untuk indiidual complaint, investigasi, dan country visit. Pembatasan perlindungan HAM jelas nyata nampak untuk dari ToR AICHR Pasal 2 yang juga menetapkan sejumlah prinsip yang harus dijadikan rujukan AICHR dalam pelaksanaan tugasnya yakni salah satunya untuk menghormati prinsip nonintervensi terhadap permasalahan internal negara-negara anggota ASEAN. Sedangkan prinsip penerapan perlindungan HAM secara praktis dan efektif tersebut tereduksi secara sistemik oleh lima (5) faktor penentu pelaksanaannya di level nasional yaitu: (1). adanya kesenjangan antara das Sollen dan das Sein (teori dengan praktek); (2). kemungkinan terjadinya kekosongan hukum (legal lacunae atau leemten in het recht); (3). kekaburan norma hukum atau bias dan deviasi norma hukum (vege normen); (4). kemungkinan tumpang tindihnya aturan hukum (legal overlapping) dan munculnya konflik norma hukum (conflict of rules).

Fungsi-fungsi yang dijalankan berdasarkan 14 mandat yang ada dalam TOR AICHR pun hampir seluruhnya untuk menjalankan fungsi promosi. Fungsi promosi yang dimilki oleh AICHR untuk melakukan upaya-upaya dalam mempromosikan HAM. Seperti dialog-dialog, menjadi konsultan badan-badan sektoral ASEAN yang terkait dengan HAM. Sedangkan fungsi proteksi yaitu fungsi dimana AICHR melakukan upaya-upaya untuk menjaga HAM di kawasan Asia Tenggara tidak bisa dijalankan dengan optimal oleh AICHR. Untuk memperkuat fungsi proteksi ini, Indonesia pada saat pembentukan TOR AICHR mengajukan 2 point mandat untuk AICHR yaitu investigation dan individual complaint. Tetapi mandat ini ditolak oleh negara-negara lainnya saat itu. Sehingga lemahnya fungsi proteksi sampai saat ini tidak lepas dari prinsip non-intervensi dan konsensus, terlebih terdapat perbedaan latar belakang dari tiap negara anggota. Hal ini berpengaruh terhadap kasus-kasus pelanggaran HAM di kawasan ASEAN. Begitu banyak pelanggaran terjadi dan juga begitu banyak laporan yang masuk ke AICHR, akan tetapi AICHR tidak mempunyai kewenangan untuk menindak laporan-laporan tersebut karena prinsip non intervensi. Sehingga yang bisa dilakukan oleh AICHR adalah membawa laporan-laporan tersebut ke dalam ASEAN Foreign Ministers Meeting (AMM). Sempat dibahas juga terkait kasus pelanggaran HAM terhadap etnis Rohingya di Myanmar pada ASEAN Foreign Ministers Meeting (AMM) ke 48 di Kuala Lumpur, Malaysia pada 4 Agustus 2015. Hal tersebut semakin mendeskripsikan bahwa segala kasus pelanggaran HAM yang dilaporkan ke AICHR tidak dapat ditindaklanjuti karena tidak ada dalam mandat yang diberikan. Mandat yang ditawarkan pada saat pembentukan TOR untuk investigation dan individual complaint tidak disetujui oleh negaranegara lainnya, bukti bahwa konsensus menjadi prinsip superior.

Hanya berfokus pada reporting daripada investigating atau bahkan penegakan nilai-nilai HAM, pelaksanaannya yang masih terbatas pada isu-isu tertentu, serta prinsip non-intervensi yang dominan dipakai sebagai upaya meningkatkan tameng kedaulatan sebuah negara tanpa memperhatikan arti penting nilai-nilai kemanusiaan yang menjadi modalitas utama berjayanya sebuah negara. Kesulitan penegakan HAM menjadi semakin komplek ketika praktek-praktek pelanggaran HAM terjadi di tingkat domestik. Sehingga pembahasan masalah HAM hanya dapat dilakukan dalam tingkat dialog. Terlebih ketika negara yang berkonflik tidak ada azas demokratis, maka penegakan HAM tidak akan ada kemajuan. Untuk negara otoritarian mereka melihat HAM sebagai ancaman. Sehingga sanksi juga tidak dapat menjatuhkan sanksi atas pelanggaran HAM yang terjadi di suatu Negara. Legitimasi yuridis dalam hal ini seharusnya 
memegang peranan penting untuk menjamin bahwa setiap manusia tanpa memandang ras, agama, suku, dan bangsa berhak untuk hidup secara layak sebagai makhluk Tuhan yang harus diperlakukan dengan baik. legitimasi nama baik

\section{f. Kesenjangan antara das Sollen dan das Sein Perlindungan HAM}

Kesenjangan antara das Sollen dengan das Sein dalam perlindungan HAM oleh Badan HAM ASEAN dapat diformulasi- kan dalam tiga bentuk kecenderungan berikut, yaitu: (1). Adanya limitasi legal personality; (2). Menguatnya reduksi efektivitas legal personality; dan (3). Melemahnya komitmen (low politics) dalam penegakan perlindungan HAM. Ketiga kecenderungan tersebut dielaborasikan menjadi: Pertama, transformasi mendasar yang dilakukan oleh Piagam ASEAN adalah memberikan legal personality kepada ASEAN dan organ bentukannnya yaitu AICHR. Legal personality yang dimiliki oleh AICHR adalah kewenangan hukum untuk bertindak yang dijamin oleh hukum internasional. Promosi perlindungan HAM yang belum sampai pada kewenangan proteksi HAM di wilayah suatu negara anggota adalah perbedaan mendasar antara das Sollen dengan das Sein yang dimiliki oleh Badan HAM ASEAN tersebut ketika dibandingkan dengan kewenangan badan-badan HAM lainnya. Inilah yang disebut sebagai limitasi dan reduksi atas legal personality yang dimilikinya dalam konteks kewenangan bertindaknya. ${ }^{7}$ AICHR tidak memiliki kewenangan penegakan hukum perlindungan HAM di negara-negara anggota (independent enforcement power) selain hanya bisa berperan sebagai badan penasihat, koordinasi dan konsultasi (low politics matters) di dalam perlindungan HAM di ASEAN itu sendiri dan kewenangan itu tidak sampai pada level taktis di wilayah negara anggota ASEAN berupa upaya advokasi dan ajudikasi. Kedua, motivasi pembentukan ASEAN adalah didasarkan pada keinginan untuk meningkatkan kerjasama dibidang ekonomi dan peningkatan kemakmuran bagi semua anggota. Motivasi ini lebih didasarkan pada pendekatan pemenuhan kebutuhan (need-based approach) daripada motivasi pemenuhan hak asasi manusia yang seharusnya menjadi landasan kerja sama regional berdasarkan pendekatan berbasis hak asasi manusia (human rights-based approach).

Pendekatan yang digunakan oleh AICHR dalam keterlibatannya pada setiap kasus pelanggaran HAM pun berbeda dengan komisi HAM di kawasan lain seperti Eropa. Sistem HAM Eropa menjalankan mekanisme HAM bicameral dimana mereka memiliki ECHR yang berfungsi untuk mempromosikan HAM di kawasan Eropa dan ECtHR yang berwenang untuk pengaduan dan peradilan internasional dalam upaya perlindungan HAM. ${ }^{8}$ Sebaliknya, AICHR tidak mempunyai mekanisme pengaduan dan peradilan sendiri. Perannya hanya dianggap oleh para anggotanya sebagai penghasil forum atau pertemuan untuk membahas dan mendiskusikan masalah-masalah yang sedang dihadapi oleh mereka. AICHR hanya dipersepsikan sebagai sebuah arena oleh negara-negara anggotanya. Hal ini disebabkan karena dalam pengambilan keputusan, AICHR mengutamakan konsensus melalui pelaksanaan pertemuan rutin dua kali dalam setahun. Jika dibutuhkan, AICHR dapat mengadakan pertemuan tambahan apabila semua perwakilan AICHR dari masing-masing negara anggota menyetujui. ${ }^{9}$

7 Heribertus Jaka Triyana, "Tinjauan Yuridis Tentang Badan HAM ASEAN Dalam Sistem Hujum Nasional di Indonesia”, diakses darihttp://download.portalgaruda. org/article.php? article $=281587 \& \mathrm{val}=7175 \&$ title $=$ tinjauan $\% 20 \mathrm{y}$ uridis $\% 20 \operatorname{tentan} \% 20 \mathrm{~g} \% 20$ badan\%20ham\%20asean\%20dalam\%20sistem\%20hukum\%20nasional\%20indonesia, pada tanggal 06 Juni 2020.

8 Djafar, Wahyudi, dkk. (2014). Memperkuat Perlindungan Hak Asasi Manusia di ASEAN. Jakarta: INFID \& ICCO. ${ }^{9}$ AICHR. 2009. ASEAN Intergovernmental Commission on Human Rights Terms of Reference. Jakarta: ASEAN Secretariat. 
Oleh karena itu, identitas AICHR seolah-olah hanya dijadikan event organizer yang dipaksa untuk mengadakan pertemuan terlebih dahulu dalam upaya merespon kasus-kasus pelanggaran HAM yang terjadi di ASEAN. Mengingat aduan masyarakat terhadap AICHR tentang pelanggaran HAM di negara-negara Asean terbilang mengalir deras. Namun, tak ada satupun pernyataan dari AICHR yang menyebut telah menerima laporan. Hal itu dipastikan, dengan tidak adanya aksi yang dilakukan oleh AICHR dalam melanjutkan laporan-laporan yang mereka terima. Terdapat sejumlah kendala dalam kerangka acuan (TOR) yang menyebabkan AICHR gagal mengatasi masalah HAM di Asean. Dengan kata lain, rakyat Asean tidak memiliki mekanisme perlindungan HAM yang memadai untuk memfasilitasi aduannya. ${ }^{9}$ Sehingga implementasi dari komitmen terhadap TOR AICHR seolah hanya menjadi alat dari kepentingan politik negara-negara Asean.

\section{g. Kekaburan Norma dan Mekanisme Hukum pada AICHR}

Kekaburan norma dan mekanisme hukum perlindungan HAM ASEAN oleh Badan HAM ASEAN terletak pada tiga hal, yaitu: (1) Ada tidaknya jaminan kepastian hukum bahwa kewenangan perlindungan hukum yang dimilikinya adalah sebagai pelengkap dari sistem norma dan mekanisme hukum nasional dan internasional dan bukan sebagai duplikasi dari norma dan mekanisme yang telah ada; (2) Ada tidaknya suatu rule of engagement (RoE) yang dimiliki oleh Badan HAM ASEAN terkait dengan upaya diseminasi HAM yang menjadi domain dari lembaga HAM nasional di negara-negara anggota ASEAN (national human rights institutions (NHRI); dan (3) Ada tidaknya mekanisme konsultasi dan koordinasi yang dimiliki oleh lembaga swadaya masyarakat (LSM) yang bergerak di bidang perlindungan HAM terhadap Badan HAM ASEAN. Pertama, jika dicermati secara kontekstual, formulasi kewenangan perlindungan hukum oleh Badan HAM ASEAN tersebut lebih menekankan pada tindakan perlindungan hukum yang kuratif atas sebuah perbuatan-perbuatan atau kejadian hukum pelanggaran HAM yang telah terjadi. Konsekuensi logisnya adalah intervensinya cenderung bersifat maskulin karena jika dilihat alur reparasinya bertumpu pada tindakan tanggap darurat yang menekankan pada aspek rekonstruksi dan rehabilitasi atas suatu pelanggaran di tingkat pemerintah dan bukan langsung kepada stakeholder utama perlindungan HAM. ${ }^{10}$

\section{Kontribusi ICC Sebagai Lembaga Pengadilan HAM Internasional}

\section{a. Yurisdiksi ICC Dalam Menangani Kasus Genosida Etnis Rohingya}

Keberadaan Etnis Rohingya yang dihilangkan oleh pemerintah Myanmar melalui pembunuhan termasuk dalam kategori tindak pidana genosida karena dalam Statuta Roma 1998 tidak menyebutkan jumlah korban minimal bahwa tindakan tersebut merupakan genosida. Hal ini berarti bahwa satu korban saja yang ditimbulkan dari tindakan yang sebagaimana dijelaskan dalam Pasal 6, dapat dikatakan sebagai genosida. ICC sendiri dapat melaksanakan kewenangannya atas suatu kasus jika negara yang mempunyai yurisdiksi atas

9 Fauzi Gilang. (2014). Komisi Ham Asean Dinilai Tak Bermanfaat. Diakses

Dari

Https://Www.Cnnindonesia.Com/Nasional/20141106165649-12-10094/Komisi-

Ham-Asean-Dinilai-TakBermanfaat, pada tanggal 09 Juni 2019, pukul 17.54 WIB.

10 Heribertus Jaka Triyana. Tinjauan Yuridis Tentang Badan HAM ASEAN

Dalam Sistem Hukum Nasional di Indonesia. Diakses darihttp://download.portalgaruda. org/article.php? article $=281587 \&$ val $=7175 \&$ title $=$ tinjauan $\% 20 y$ uridis $\% 20 \operatorname{tentan} \% 20 \mathrm{~g} \% 20$ badan\%20ham\%20asean\%20dalam\%20sistem\%20hukum\%20nasional\%20indonesia, pada tanggal 16 Juni 2020, pukul 14.34 WIB. 
kasus, sungguhsungguh tidak mau (unwilling) atau tidak mampu (unable) untuk melakukan penyidikan atau penuntutan. Pasal 17 Statuta Roma 1998 mengatur bahwa ICC tidak dapat melaksanakan yurisdiksi berdasarkan beberapa alasan. Pertama, kasus tersebut sedang disidik dan dituntut oleh negara yang memiliki yurisdiksi atas kasus, kecuali negara tersebut sungguhsungguh tidak mau (unwilling) atau tidak mampu (unable); kedua, kasus itu telah diselidiki oleh negara yang mempunyai yurisdiksi terhadapnya dan negara itu telah memutuskan tidak menuntut individu tersebut; ketiga, individu yang bersangkutan telah dihukum; keempat, kasus itu cukup bukti untuk membenarkan tindakan-tindakan lebih lanjut oleh pengadilan. Ketentuan Pasal 17 ayat (2) Statuta Roma 1998 menjelaskan bahwa ICC dapat melaksanakan yurisdiksi apabila salah satu syaratnya sistem pengadilan nasional suatu negara unwilling.

Ketentuan Pasal 17 ayat (3) Statuta Roma 1998 menjelaskan bahwa ICC akan mempertimbangkan indikator (unable) ketidakmampuan, baik itu ketidakmampuan secara menyeluruh atau kegagalan substansial, sehingga sistem peradilan nasional tidak dapat melaksanakan sendiri proses persidangan. Berdasarkan penjelasan Pasal 17 Statuta Roma 1998, indikator mengenai unwilling atau unable pada dasarnya berlaku pada negara yang telah meratifikasi. Bagi negara yang belum meratifikasi, seperti pada negara Myanmar, maka dasar agar ICC dapat melaksanakan kewenangannya dapat dilihat dalam Pasal 12 Statuta Roma 1998. Pasal tersebut menjelaskan apabila suatu pelanggaran terjadi pada negara yang bukan pihak peratifikasi statuta, maka harus mengajukan pernyataan yang diajukan ke kantor panitera bahwa negara tersebut menerima pelaksanaan yurisdiksi ICC. Ketentuan Pasal 13 Statuta Roma 1998 juga dapat dijadikan landasan berlakunya ICC atas kasus Rohingya. Pasal 13 mengatur bahwa ICC dapat melaksanakan yurisdiksi penanganan terhadap pelanggaran HAM berat, apabila kasus tersebut diajukan oleh negara peserta Statuta, atas rekomendasi dari Dewan Keamanan Perserikatan Bangsa-Bangsa (DK PBB) sesuai dengan Bab VII Piagam PBB, dan atas inisiatif dari Penuntut ICC. Hal ini tidak jauh berbeda dengan Pasal 16 Statuta yang mengatur mengenai penundaan penuntutan yang juga didasarkan atas keputusan DK PBB, sehingga dalam hal ini keputusan DK PBB dapat digunakan untuk menyelesaikan kasus Rohingya dan dapat mempengaruhi keamanan dan perdamaian dunia. ${ }^{11}$

\section{b. Kelemahan ICC Dalam Mengatasi Kasus Pelanggaran HAM di ASEAN}

Kritik tak lepas dari kiprah ICC dalam mengusut para pelaku kejahatan HAM. ICC, misalnya, dipandang tak punya otoritas yang kuat untuk menghukum pelaku sehingga membuat kerjakerja mereka tidak efektif dan efisien. Sedangkan yang lain beranggapan bahwa ICC kelewat banyak menjatuhkan tuntutan, mengancam kedaulatan negara, serta tak jarang bias politik. Ada pula yang menyebut hakim-hakim ICC tak cukup kredibel dalam mengusut kasus sampai tuntas. Di lain sisi, banyak dari negara-negara di Afrika yang memandang ICC bekerja secara tidak proporsional. Anggapan ini muncul dari total puluhan kasus yang diusut, sebagian besar berasal dari Afrika. Pada 2013, kenyataannya bahkan meminta anggota Uni Afrika untuk menarik dukungannya terhadap ICC. Empat tahun kemudian, gema penolakan itu kian kuat. Kerja ICC makin terjepit melihat fakta bahwa negara-negara poros utama seperti Amerika, Cina, dan Rusia tak memberikan dukungan dengan penuh. Khusus AS, ICC punya relasi yang bisa dikatakan naikturun.

Saat pemerintahan Bill Clinton, dapat diambil contoh, AS mendukung konsep pengadilan pidana internasional serta turut ambil bagian dalam penyusunan Statuta Roma. Namun, dukungan itu tak dilanjuti secara serius oleh Clinton sebab ICC dinilai bisa mempolitisasi

11 Ayyub Tori Satrio Kusumo. (2014). Optimalisasi Peran International Criminal Court dan Aplikasi aksi Kemanuasiaan Sebagai Inisiasi Penyelesaian Kasus Etnis Rohingya. Jurnal Dinamika Hukum, Vol. 4 No 3. 
kebijakannya sehingga berefek pada keberadaan tentara AS di medan perang seperti Timur Tengah. Sikap serupa tetap dipertahankan sampai Trump berkuasa. Pada September 2018, Penasihat Keamanan Nasional, John Bolton, mengumumkan bahwa Washington tidak akan bekerja sama dengan ICC dan memblokir seluruh upaya penyelidikan terhadap warga AS maupun Israel dalam konflik militer maupun politik yang ada. Ancaman kembali dipertegas setelah Menteri Luar Negeri, Mike Pompeo, mengeluarkan pernyataan bakal mencabut visa staf ICC yang menyelidiki kasus-kasus yang melibatkan AS terutama di Afghanistan. Pelanggaran HAM internasional meninggalkan trauma yang berat. Dan upaya untuk mengusutnya tak kalah memberatkan. ${ }^{12}$

\section{c. Titik Urgensi Diibentuknya Pengadilan HAM}

Urgensi pendirian Pengadilan HAM sangat terjawab dengan penjelasan fakta-fakta yang selama ini terjadi selama AICHR berdiri dan bertugas. AICHR yang sebenarnya memiliki mandat untuk melakukan tidak hanya sebatas promotion namun juga protection, hingga periode ini baru dapat melaksanakan fungsi promotion saja. Beberapa kasus yang diduga terjadi pelanggaran HAM di dalamnya yang sudah dilaporkan kepada AICHR tidak mendapat tanggapan apapun dalam penegakan hukumnya. Hal ini juga disebabkan oleh tidak legally binding-nya AHRD bagi seluruh negara anggota ASEAN yang menyebabkan tidak ada kewajiban secara hukum bagi negara anggota untuk mengimplementasikan deklarasi ini di dalam hukum nasional. Selain itu, AHRD yang juga memberikan sebagian HAM untuk diatur di masing-masing hukum nasional sehingga terjadi partikularisasi HAM yang seharusnya bersifat universal. Mekanisme HAM Regional di

ASEAN yang belum terbentuk, nantinya akan mengandung beberapa unsur-unsur yang berbeda dengan regional lainnya. Mekanisme HAM Regional di Afrika, Amerika, dan Eropa mampu menjadi role mode bagi ASEAN untuk pembentukan mekanismenya sendiri. Namun, kembali kepada the origins of ASEAN di mana dikenal beberapa istilah seperti ASEAN Way dan NonInterfence Principles yang sangat memberikan efek atau pengaruh terhadap mekanisme HAM regional yang dimiliki oleh ASEAN sehingga mekanisme tersebut harus menyesuaikan dengan prinsip-prinsip yang tidak bisa dihilangkan dari ASEAN. Sehingga, pembetukan Pengadilan HAM ASEAN yang mungkin masih memerlukan waktu dan jalan yang sangat panjang, menjadi lebih mudah ketika prinsip-prinsip ASEAN dan political will dari masing-masing Negara Anggota ASEAN disatukan untuk penegakan keadilan terhadap HAM di ASEAN. ${ }^{13}$ Dengan adanya pengadilan HAM, nantinya akan melengkapi fungsi proteksi yang dimiliki oleh AICHR (ASEAN Intergovernmental Commission on Human Rights) berada di bawah AICHR. Jadi selain memberikan fungsi promosi HAM di ASEAN, AICHR juga memiliki fungsi proteksi dan mampu memberikan keputusan terhadap kasus-kasus pelanggaran HAM yang terjadi di dalam ASEAN. Ini bisa diterapkan bukan hanya pada kasus pelangaran HAM penduduk Rohingya, namun juga pada kasus terorisme, genosida, perdagangan manusia dan lainnya. Dengan adanya pengadilan HAM ini, prinsip non-intervensi yang dimiliki oleh ASEAN tidak akan dilanggar. Pengadilan ini hanya akan mengambil kasus HAM di suatu Negara apabila Negara tersebut unwilling (tidak mau) dan unable (tidak mampu) untuk menyelesaikan masalahnya sendiri. ${ }^{14}$

12 Tirtoid. (2019). Cara Kerja dan Kritik terhadap Pengadilan Pidana Internasional. Diakses dari https://tirto.id/carakerja-dan-kritik-terhadap-pengadilan-pidana-internasional-elmZ, pada tanggal 15 Juni 2020.

13 Ayu Hannah Zaimah. (2015). Urgensi Pembentukan Pengadilan Hak Asasi Manusia (Ham) Oleh Asean InterGovernmental Comission On Human Rights (AICHR). 14 BPH UMY. 2017. Ajukan Pembentukan Pengadilan HAM Tingkat ASEAN, 


\section{Konsekuensi Apabila Dibentuk Sebuah Pengadilan HAM Regional}

\section{a. Konflik Yurisdiksi dengan ICC}

Dalam hal penerapan yurisdiksi ICC pada suatu Negara, terdapat prinsip yang paling fundamental, yakni ICC harus merupakan komplementer (pelengkap) dari yurisdiksi pidana nasional suatu negara (complementarity principle). Fungsi ICC bukanlah untuk menggantikan fungsi sistem hukum nasional suatu negara, namun ICC merupakan mekanisme pelengkap bagi Negara ketika negara menunjukkan ketidakmauan (unwillingness) atau ketidakmampuan (inability) untuk menghukum pelaku kejahatan yang merupakan yurisdiksi ICC. Selanjutnya Statuta Roma menegaskan bahwa pengadilan nasional yang merupakan kedaulatan suatu negara tidak dapat dikontrol oleh ICC. Prinsip komplementer berlaku juga terhadap negara yang bukan merupakan negara pihak akan tetapi memberikan pernyataan pengakuannya atas yurisdiksi ICC.

Dengan demikian, ICC merupakan the last resort dan hal ini merupakan jaminan bahwa ICC bertujuan untuk mengefektifkan sistem pengadilan pidana nasional suatu negara.

Adapun Yurisdiksi ICC terbagi ke dalam empat jenis, sebagai berikut:

a. territorial jurisdiction; bahwa yurisdiksi ICC hanya berlaku dalam wilayah negara pihak; yurisdiksi juga diperluas bagi kapal atau pesawat terbang yang terdaftar dinegara pihak dan dalam wilayah bukan negara pihak yang mengakui yurisdiksi ICC berdasarkan deklarasi Ad hoc.

b. material jurisdiction; bahwa kejahatan yang menjadi yurisdiksi ICC terdiri dari kejahatan tehadap kemanusian, kejahatan perang, kejahatan agresi dan genosida.

c. temporal jurisdiction (rationae temporis); bahwa ICC baru memiliki yurisdiksi terhadap kejahatan yang diatur dalam Statuta setelah Statuta Roma berlaku/diratifikasi.

d. personaljurisdiction(rationaepersonae); bahwaICCmemilikiyurisdiksiatasorang(natural person), dimana pelaku kejahatan dalam yurisdiksi ICC harus mempertanggungjawabkan perbuatannya secara individu (individual criminal responsibility), termasuk pejabat pemerintahan, komandan militer maupun atasan sipil. ${ }^{15}$

Sehingga ketika pengadilan HAM regional dibentuk, maka konflik yurisdiksi akan terjadi karena ICC akan menjadi badan lebih komplementer dari sebelumnya yang hanya menjadi komplementer negara, menjadi komplementer suatu wilayah regional yang didalamnya terdapat berbagai negara dengan political diversity yang berpotensi lebih merancukan adanya suatu kewenangan lembaga karena ada kepentingan tertentu. Mengingat asas konsensus tetaplah menjadi dasar hukum pengambilan keputusan.

\section{Regulasi antara Pengadilan HAM Regional Berpotensi Tumpang Tindih dengan ICC}

Saat ini permasalahan aturan Undang-Undang di Indonesia banyak yang tumpang tindih dan disharmoni. ${ }^{17}$ Saat ini ada terlalu banyak peraturan. Menurut data milik Kemenkumham,

Mahasiswa IPOLS Raih Mahasiswa Berprestasi se-Kopertis Wilayah V. Diakses dari http:// www.umy.ac.id/ajukan-pembentukan-pengadilan-hamtingkat-asean-mahasiswa-ipolsraih-mahasiswa-berprestasi-se-kopertis-wilayah-v.html, pada tanggal 05 Juni 2020.

15 Sefriani. (2007). Yurisdiksi ICC Terhadap Non Anggota Statuta Roma 1998. JURNAL HUKUM NO. 2 VOL. $14{ }^{17}$ Hariyanto, Ibnu. 2016. Menku HAM Ungkap Penyebab Banyak UU Masih Tumpang Tindih. Diakses dari https://news.detik.com/ berita/d-3334692/menkum-ham-ungkap-penyebab-banyak-uu-masih-tumpang-tindih, pada tanggal 10 Juni 2020. 
saat ini ada lebih dari 42 ribu peraturan yang terdiri dari: lebih dari 8 ribu peraturan pusat (undangundang, peraturan pengganti undang-undang, peraturan pemerintah, dan peraturan presiden); 13 ribu peraturan menteri; 3 ribu peraturan lembaga pemerintahan non kementerian; dan 15 ribu peraturan daerah. Banyak peraturan ini bahkan saling tumpang tindih, sehingga menimbulkan masalah serius karena tidak selaras satu sama lain. Sehingga apabila suatu pengadilan HAM regional dibentuk, maka juga akan menimbulkan banyak aturan baru yang berpotensi saling tumpang tindih dan disharmoni. Mengingat aturan hukum yang tumpang tindih dapat disebabkan oleh beberapa hal:

\section{a. Ego sektoral}

Ada anggapan bahwa regulasi adalah solusi dari setiap persoalan, serta juga dijadikan tolak ukur keberhasilan dari sebuah lembaga. Akibatnya, mereka berlomba-lomba membentuk regulasi. Namun, karena mengutamakan kepentingan masing-masing, sehingga yang muncul adalah peraturan yang tidak efektif dan saling tumpang tindih. Beberapa lembaga bahkan terlibat dalam konflik kewenangan. Mereka mengeluarkan peraturan, yang materi muatannya bersinggungan dengan mementingkan kewenangannya masing-masing.

\section{b. Masalah kelembagaan}

Tidak ada lembaga yang memiliki wewenang kuat untuk melakukan pengawasan dan penilaian terhadap peraturan perundang-undangan yang ada, baik pada tahap pembentukan maupun setelah peraturan perundang-undangan tersebut disahkan dan dinyatakan berlaku.

\section{c. Kerugian akibat hukum yang tidak sinkron}

Jika aturan-aturan hukum yang dikeluarkan tidak dapat diharmonisasikan, maka akibatnya adalah: Pertama, akan banyak peraturan yang diuji materi karena saling bertentangan. Hal ini akan menyebabkan kualitas peraturan perundang-undangan yang dibentuk terus dipertanyakan. Kedua, menimbulkan berbagai keluhan tentang kepastian hukum. Dapat diketahui faktanya, aturan yang tidak mengalami konflik, masih banyak persoalan/kasus yang belum dapat diselesaikan karena berbagai faktor kepentingan plitik masing-masing negara, tentunya dengan adanya ketidakpastian hukum, maka pengadilan HAM ASEAN akan tersandera peraturan yang dibuatnya sendiri karena jumlahnya yang terlalu banyak. Terlebih adanya ketidaksinkronan hukum HAM regional dengan internasional, ini sangat penting untuk menghindari konflik kepentingan. Ketiga, peraturan yang terlalu banyak akan melemahkan pelaksanaan. Ketaatan hukum tidak bisa terwujud bila tidak jelas aturan mana yang harus dipatuhi. Padahal, aturan dibuat untuk menjawab persoalan, memberikan kepastian hukum. Sehingga konsekuensi logisnya, akan ada lembaga yang harus dilemahkan pelaksanaan kewenangan agar bisa mengoptimalkan peran lembaga lain.

Pada akhirnya, pembentukan lembaga khusus berupa pengadilan HAM regional akan memberikan kerancuan dalam penegakan HAM di negara ASEAN. Wilayah hukum, dalam hal, ini diwujudkan melalui kelembagaan, penegakkan hukum, budaya hukum, dan subtansi dari peraturan perundang-undangan tidak saling tumpang tindih. Selain itu, regulasi yang berkualitas baik adalah yang efektif dalam implementasi, tidak memiliki konflik kepentingan serta menjamin hak warga negara. Dengan adanya lembaga tersebut, ASEAN harus dapat menunjukkan keseriusannya dalam melakukan pembangunan hukum, yakni menciptakan hukum untuk mewujudkan kebenaran dan keadilan, serta sejalan dengan kebutuhan hukum masyarakat, dengan berdasarkan pada Pancasila sebagai dasar negara ${ }^{16}$. Faktanya, persoalan

16 Putra Antoni. (2019). Jokowi Ingin Bentuk Badan Regulasi Nasional Untuk

Cegah Peraturan tumpang-tindih, perlukah?. Diakses dari http://theconversation.com/ 
tumpang tindih sangat kompleks, dan jenis peraturan tumpang tindih sangat banyak. Sehingga penguatan pembentukan itu berbasis pada politik hukum yang jelas dan penyamaan persepsi para pemangku kepentingan bidang regulasi. Persoalan ego sektoral sudah berkali-kali disebut sebagai penyumbang banyaknya tumpang tindih peraturan. Masing-masing lembaga mengatur masalah tertentu tanpa memikirkan lebih jauh imbasnya pada kewenangan lembaga lain. Upaya ASEAN menata regulasi yang secara intensif tentu mendapat tantangan yang relative lebih berat dalam masa selanjutnya.

\section{KESIMPULAN}

Jika ASEAN terus berlindung dibalik tameng prinsip non-intervensi, setiap permasalahan yang terdapat di dalam anggota ASEAN cenderung menjadi berlarut-larut dan menjadi sorotan dunia internasional. Mengingat pandangan hak asasi manusia terhadap prinsip non-intervensi sangat bertolak belakang dalam pelaksanaannya. Negara yang seharusnya bisa memberikan perlindungan, penghormatan dan pemenuhan hak asiasi manusia bagi warga negaranya. Hal yang demikian juga telah tertuang dalam prinsip-prinsip HAM diantaranya adalah prinsip tanggung jawab negara dan penegakan hukum (state responsibility and rule of law). Seandainya negara gagal dalam melaksanakan tanggung jawabnya, maka pihak-pihak yang dirugikan berhak untuk mengajukan tuntutan kepada negara secara layak yang sesuai dengan aturan dan prosedur hukum yang berlaku. Hadirnya AICHR memang sangat diperlukan mengingat Asia Tenggara merupakan salah satu kawasan yang memiliki banyak sekali kasus pelanggaran HAM. AICHR sudah melakukan fungsi promosinya dengan baik untuk secara perlahan mendorong negara-negara ASEAN menyadari pentingnya melakukan perlindungan HAM. Namun berdasarkan perkembangannya, komisi HAM regional ini masih mengalami beberapa hambatan. Terdapat beberapa faktor penghambat AICHR dalam penegakan HAM di Asia Tenggara, di antaranya prinsip ASEAN Way dimana penggunaan prinsip non intervensi dan kedaulatan negara ASEAN untuk hak asasi manusia yang masih belum fleksibel; pengambilan keputusan berdasarkan konsensus yang membuat kinerja AICHR menjadi terhambat karena harus mendapat suara bulat dari seluruh negara anggota ASEAN; lemahnya mandat fungsi proteksi dalam ToR AICHR karena tidak tercapainya konsensus pada tahun 2010 ketika Indonesia mengajukan mandat perlindungan dasar untuk AICHR; adanya kepentingan politik dari masing-masing negara ASEAN seperti tidak dibahasnya suatu isu yang diangkat karena belum menjadi prioritas di negara tersebut serta tidak dibahasnya sebuah isu oleh suatu negara apabila isu tersebut bersifat sensitif pada rezim suatu negara.

\section{DAFTAR PUSTAKA}

AICHR. (2009). ASEAN Intergovernmental Commission on Human Rights Terms of Reference. Jakarta: ASEAN Secretariat.

AICHR. (2019). Prospek Mekanisme HAM ASEAN. Diakses dari https://aichr.or.id/index. $\mathrm{php/id/aichr-indonesia/akuntabilitas-publik/rilis/23} \mathrm{prospekmekanisme-ham-}$ asean?showall $=\&$ start $=4$, pada tanggal 15 Juni 2020, pukul 17.56 WIB.

Ayu Hannah Zaimah. (2015). Urgensi Pembentukan Pengadilan Hak Asasi Manusia (Ham) Oleh Asean Inter-Governmental Comission On Human Rights (AICHR).

Ayyub Tori Satrio Kusumo. 2014. Optimalisasi Peran International Criminal Court dan

jokowi-ingin-bentuk-badan-regulasi-nasional-untukcegah-peraturan-tumpang-tindihperlukah-120343, pada tanggal 09 Juni 2020. 
Aplikasi aksi Kemanusiaan Sebagai Inisiasi Penyelesaian Kasus Etnis Rohingya. Jurnal Dinamika Hukum, Vol. 4 No 3.

BPH UMY. 2017. Ajukan Pembentukan Pengadilan HAM Tingkat ASEAN, Mahasiswa IPOLS Raih Mahasiswa Berprestasi se-Kopertis Wilayah V. Diakses dari http://www. umy.ac.id/ajukan-pembentukan-pengadilan-ham-tingkat-aseanmahasiswaipols-raihmahasiswa-berprestasi-se-kopertis-wilayah-v.html, pada tanggal 05 Juni 2020, pukul 17.54 WIB.

Djafar, Wahyudi, dkk. 2014. Memperkuat Perlindungan Hak Asasi Manusia di ASEAN. Jakarta: INFID \& ICCO.

Fauzi Gilang. 2014. Komisi Ham Asean Dinilai Tak Bermanfaat. Diakses dari Https://www. Cnnindonesia.Com/Nasional/20141106165649-12-10094/Komisi-Ham-

Asean-Dinilai-Tak-Bermanfaat, pada pada tanggal 09 Juni 2019, pukul 17.54 WIB.

Fiari Larasati, dkk. 2017. Faktor-Faktor Penghambat Asean Intergovernmental Commission on Human Rights (Aichr) Dalam Penegakan Hak Asasi Manusia di Asia Tenggara. Dinamika Global, Volume 02, No.01.

Hariyanto, Ibnu. 2016. Menku HAM Ungkap Penyebab Banyak UU Masih Tumpang Tindih. Diakses dari https://news.detik.com/berita/d-3334692/menkum-ham-ungkappenyebabbanyak-uu-masih-tumpang-tindih, pada tanggal 10 Juni 2020.

Jaka Triyana, Heribertus. Tinjauan Yuridis Tentang Badan HAM ASEAN Dalam Sistem Hujum

Nasional di Indonesia. Diakses dari http://download.portalgaruda. org/article.php?article $=281587 \& \mathrm{val}=7175 \&$ title $=$ tinjauan $\%$ ur $\quad$ idis $\% 20 \operatorname{tentan} \% 20$ g\%20badan\%20ham\%20asean\%20dalam\%20sistem\%20hukum\%20nasi onal\%20 indonesia, pada tanggal 16 Juni 2020, pukul 14.31 WITA.

Kirsten Han, Teguh ahap. 2018. Menimbang efisiensi AICHR untuk perjuangan HAM di ASEAN. Diakses dari https://newnaratif.com/journalism/menimbang-efisiensi-aichruntukperjuangan-ham-di-asean/share/xuna/acfe22eeddf82266e32f8f17912d59fe/, pada tanggal 03 Juni 2020, pukul 16.37 WITA.

Putra Antoni. 2019. Jokowi Ingin Bentuk Badan Regulasi Nasional Untuk Cegah Peraturan tumpang-tindih, perlukah?. Diakses dari http://theconversation.com/jokowiingin-bentukbadan-regulasi-nasional-untuk-cegah-peraturan-tumpang-tindihperlukah-120343, pada tanggal 09 Juni 2020.

Sefriani. 2007. Yurisdiksi ICC Terhadap Non Anggota Statuta Roma 1998. JURNAL HUKUM NO. 2 VOL. 14.

Soekanto, S., \& Mamudji, S. 2011. Penelitian Hukum Normatif Suatu Tinjauan Singkat, Jakarta: PT Raja Grafindo Persada.

Tirtoid. 2019 Cara Kerja dan Kritik terhadap Pengadilan Pidana Internasional. Diakses dari https://tirto.id/cara-kerja-dan-kritik-terhadap-pengadilan-pidana-internasional-elmZ, pada tanggal 15 Desember 2019. 